\title{
GIS and Logit Regression Model Applications in Land Use/Land Cover Change and Distribution in Usangu Catchment
}

\author{
Canute Hyandye*, Christina Geoffrey Mandara, John Safari \\ Institute of Rural Development Planning (IRDP), Dodoma, Tanzania
}

Email address:

chyandye@irdp.ac.tz (C. Hyandye)

To cite this article:

Canute Hyandye, Christina Geoffrey Mandara, John Safari. GIS and Logit Regression Model Applications in Land Use/Land Cover Change and Distribution in Usangu Catchment. American Journal of Remote Sensing. Vol. 3, No. 1, 2015, pp. 6-16. doi: 10.11648/j.ajrs.20150301.12

\begin{abstract}
This study applied time series analysis to examine land use/land cover (LULC) change and distribution in Usangu watershed and multinomial logistic regression in the GIS environment to model the influence of the related driving factors. Historical land use/cover data of the watershed were extracted from the 2000, 2006 and 2013 Landsat images using GIS and remote sensing data processing and analysis techniques. Data was analyzed using ArcMap 10.1, ERDAS Imagine, SPSS and IDRISI Selva software. Eight factors likely to influence LULC change and LULC distribution were assessed. These include elevation, slope, distance from roads, distance from rivers networks, population density, Normalized Vegetation Index (NDVI), annual rainfall and soil types. Results show that LULC changes are mainly influenced by variations in annual rainfall, population density and distance from road networks. LULC distribution is determined mainly by terrain and edaphic factors namely elevation, slope and soil types. NDVI does not influence LULC change nor determine the LULC distribution, but can be used to show concentration of LULC types on a landscape. Combination of GIS, remote sensing and statistical analysis capabilities are powerful tools for assessing and model processes of land use change and their underlying causes in terms of time and space. It is concluded that ingeniously integration of remote sensing, GIS application combined with multi-source spatial data analysis give great possibility of quantifying and explaining the temporal and spatial LULC changes and distribution in a given watershed.
\end{abstract}

Keywords: LandUse/Cover, Change and Distribution, GIS, Remote Sensing, Multinomial Logit Regression, Usangu

\section{Introduction}

The transformation of land use and land cover is driven by a range of different factors and mechanisms. While climate, technology and economics are key determinants of land-use change at different spatial and temporal scales [1],geomorphology and edaphic factors determine the LULC distribution on the landscape [2] . Existence and changes of LULC in a given time and location occur as a result of many factors. These factors include political, economic, cultural, technological, and natural driving factors, including factors that derive from the spatial configuration (also referred to as natural configuration). Natural driving factors include site factors (spatial configuration, topography, and soil conditions) as well as natural disturbances such as drought, wildfires and floods which induce long term global change [3]. The LULC change distribution varies in space and time. This is because physical and social characteristics of communities vary in space and time, so do land-use choices, resulting in a spatial pattern of land-use types [4]. LULC change driving factors have been defined as the underlying elements that trigger landscape changes [5]. These factors influence the trajectories of landscape development [6]. The study of driving factors of landscape change has a long tradition in geography and landscape research [7], and is gaining increasing attention in landscape-change research. Indeed, driving factors have been identified as one of the six core concepts for the modelling of land-use change [8].

The driving factors form a complex system of dependencies and interactions and affect a whole range of temporal and spatial levels. Time series analysis of land cover changes and the identification of the driving factors responsible for these changes are neededindesigning appropriate management techniques for natural resources and also for projecting future land cover trajectories [9]. Land cover change information is needed regarding what and how changes occur, where and when they occur, the rates at which they occur, and the social and physical factors that drive those changes [10]. Good 
understanding of biological, social and physical factors which regulate and shape landuse/cover in a certain landscape is a pre-requisite towards proper eco-environment management. Understanding of land use change dynamics is foremost concerned with quantities of change [11].

Several LULC change related studies [12-14] have been carried out in Usangu catchment. However, these studies did not include spatial analyses of the driving factors of LULC change. Indeed, many studies on LULC analysis is Tanzania have focused only on quantifying the amount of the change and qualitative description of the factors causing the changes observed. To a less extent spatial-temporal and statistical analysis of the driving factors of LULC changes have been studied. Spatial analysis is instrumental in land use planning and informed decision making. In addition, spatial LULC analysis with respect to parameters like slope, elevation, annual rainfall amounts look into more interwoven and hidden factor-factor and factor LULC change relationships. The choice of factors for analysis in this study (i.e. rainfall amounts and distribution, population density) was guided by facts provided by the districts' officers in Usangu catchment as well as the common factors discussed in literature [15, 16].The contributions of each driving factor on the observed LULC change need to be identified so as to enable informed decisions while managing landscapes. The objective of this study is to assess changes and distributions of LULC in Usangu Watershed landscapes from 2000-2013. The study demonstrates applications of GIS in integrating data from various sources and use of multinomial regression approach in accounting for LULC changes and distribution.

\section{Material and Methods}

\subsection{Study Area}

Usangu sub-catchment is found in the upper part of Rufiji Basin in Tanzania. It lies between latitudes $7^{\circ} 45^{\prime}$ and $9^{\circ} 25^{\prime}$ South, and longitudes $33^{\circ} 40^{\prime}$ and $35^{\circ} 40^{\prime}$ East, covering an area of approximately $20,800 \mathrm{~km}^{2}$. About $4,840 \mathrm{~km}^{2}(23 \%)$ of the Usangu sub-catchment is in the alluvial plains below $1100 \mathrm{~m}$ above the mean sea level (amsl). The remaining $77 \%$ of the catchment area lies in the 'high catchment', which ranges in altitude from about 1,100 to over 2,000 $\mathrm{m}$ amsl. The catchment is surrounded by the Kipengere, Poroto and Chunya mountains with elevations up to $3000 \mathrm{~m}$ amsl. The Usangu catchment is vital to Tanzania for its irrigated rice production as well as for its livelihoods options for smallholder farmers and agro- pastoralists [17]

Usangu catchment is characterized by uni-modal rainfall which starts in November/December and ends in April/May [18]. The highlands surrounding the wetlands are among the areas with the heaviest rainfall in Tanzania, from where the bulk of the flow to Great Ruaha River is generated [19]. The highlands receive precipitation of about $1600 \mathrm{~mm} /$ year, while the plains receive around 500-700 mm/year [17]. Major tributaries to the Great Ruaha River with confluences in the Usangu catchment are Mbarali, Kimani, Chimala and Ndembera River.

\subsection{Data Types and Sources}

Historical land use/cover data of the watershed were extracted from the 2000, 2006 and 2013 Landsat images. Satellite imagery for land use/cover analysis was acquired through direct download from the U.S. Geological Survey website (http:\|glovis.usgs.gov). Usangu Catchment extends over three different Landsat paths and rows. The dates of the satellite imagery used in the study and their associated path and rows are shown in Table 1. The spatial resolution of these satellite images 30 meters.

Table 1. Characteristics of satellite imageries used.

\begin{tabular}{llll}
\hline Year & path168/row066 & path169/row065 & path169/row066 \\
\hline 2000 & $2000-05-11$ & $2000-07-21$ & $2000-07-21$ \\
2006 & $2006-06-05$ & $2006-05-27$ & $2006-05-27$ \\
2013 & $2013-06-08$ & $2013-05-14$ & $2013-05-14$ \\
\hline
\end{tabular}

The images were purposely selected from the US Geological Survey website, based on the growing calendar in such a way that major crops that are cultivated in the study area were still in the field. Other data used included digital elevation model, population density data, river and roads network shapefiles. Population data for 2002 and 2012 were downloaded from Tanzania Bureau of Statistics website (http://www.nbs.go.tz/). The population density for 2002 was then projected for 2006 population estimate.Data for the soil types were extracted from version (3.6) of the digitized FAO Soil Map of the World (http://www.waterbase.org/download_data.html). Soil names were coded as "Soil1, Soil2...Soil8" for subsequent analyses. Names and descriptions of soils types are presented in Table 2. Note, the satellite images and soil data were extracted from the international sources as earlier mentioned because such data could not be obtained from the country's sources.

Table 2. Soil types and their description.

\begin{tabular}{lll}
\hline Soil type & Code & Description \\
\hline Leptosols & Soill & Very shallow soils over hard rock or in unconsolidated very gravelly material \\
Fluvisols & Soil2 & Young soils in alluvial deposits \\
Cambisols & Soil3 & Weakly to moderately developed soils \\
Andosols & Soil4 & Young soils formed from volcanic deposits \\
Lixisols & Soil5 & Soils with subsurface accumulation of low activity clays and high base saturation \\
Solonetz & Soil6 & Soils with subsurface clay accumulation, rich in sodium \\
Acrisols & Soil7 & Soils with subsurface accumulation of low activity clays and low base saturation \\
Nitisols & Soils & Deep, dark red, brown or yellow clayey soils having a pronounced shiny, nut-shaped structure \\
\hline
\end{tabular}




\subsection{Data Processing and Analysis}

Satellite images were pre-processed before classification was performed. Layer stacking was performed to combine bands and then image edges were trimmed out in ArcMap using the Landsat WRS II path and raw shapefiles. Images of the same year but from different path and rows were radiometrically corrected and then mosaicked in ERDAS Imagine 2011 software [20]. Supervised classification was performed in ArcMap 10.1[21] whereby the training sites were selected based on the ground-truth GNSS(Global Satellite Navigation System) coordinates which were collected during field reconnaissance. Other ancillary data like shapefiles of roads, irrigation project maps, rivers and settlements facilitated the selection of classification training samples. Each imagery was classified into 9 landuse/cover classes as modified from Anderson scheme of landuse/cover classification [22]. Landuse/cover classes for this study and their details areshown in Table 3.

Table 3. Land use/land cover classes and their descriptions.

\begin{tabular}{ll}
\hline Class & Details \\
\hline Grassland (GRA) & Tall to short grasses, sometimes bare soils in dry season. \\
Wetland (WET) & Areas with lands partially covered with water and grasses \\
Woodland (WOD) & Areas with wood trees but less closed canopy \\
Forest (FOR) & Areas with closed trees, thick canopy, both natural and planted forests. \\
Shrubs (SHR) & Short and scatted trees, mainly thorn buses and acacia trees \\
Agricultural land (AGR) & All land with crops \\
Bare land (Rock\&Soils) (BAR) & Bare soils, rock out crops, quarry areas, sands, eroded soils \\
Water (WAT) & Rivers, water in wetlands, fish ponds and water in agricultural areas \\
Urban (URB) & Tarmac and gravel roads, concrete areas, urban and rural settlements \\
\hline
\end{tabular}

\subsection{Land Use/Cover Classification Accuracy Assessment}

The accuracy of image classification was checked using the ground truthing GNSS points data as well as other reference points which were randomly selected from the features of the satellite images. A maximum of 60 points was selected for each LULC class. As shown in Table 4, the individual accuracy of the LULC types were estimated using the producer's accuracy (omission error) and user's accuracy (commission error).

Table 4. Classification accuracy (\%) for LULC maps for the year 2000, 2006 and 2013.

\begin{tabular}{|c|c|c|c|c|c|c|}
\hline & 2000 & & 2006 & & 2013 & \\
\hline Class name & Producer Accuracy & Users Accuracy & Producer Accuracy & Users Accuracy & Producer Accuracy & Users Accuracy \\
\hline Grassland & 95.0 & 79.2 & 86.7 & 71.2 & 91.7 & 64.0 \\
\hline Wetland & 83.6 & 85.0 & 85.0 & 85.0 & 86.7 & 85.2 \\
\hline Woodland & 85.2 & 86.7 & 75.4 & 86.8 & 90.0 & 91.5 \\
\hline Forest & 91.7 & 98.2 & 93.3 & 100.0 & 90.0 & 96.4 \\
\hline Shrubs & 86.7 & 80.0 & 93.3 & 78.9 & 93.3 & 94.9 \\
\hline Agric & 90.0 & 81.8 & 86.7 & 83.9 & 90.0 & 76.1 \\
\hline Bare land (Rock\&Soils) & 97.5 & 92.9 & 75.0 & 81.1 & 66.7 & 100.0 \\
\hline Water & 81.0 & 95.9 & 86.7 & 98.1 & 75.0 & 100.0 \\
\hline Urban & 78.3 & 94.0 & 83.3 & 89.3 & 81.7 & 87.5 \\
\hline
\end{tabular}

The overall classification accuracy (\%) are 87.3, 85.4 and85.7 for 2000, 2006 and 2013, respectively while the overall kappa statistics for the same years are $0.86,0.84$ and 0.86 , respectively.

The producer's accuracy was computed by dividing the number of samples in an individual class identified correctly by the respective reference totals while the user's accuracy was computed by dividing the number of samples in an individual class identified correctly with the classified totals $[23,24]$. The overall classification accuracy was derived by dividing the total number of correctly classified landuse classes by the total number of reference data [23]. Kappa statistics, also known as $\mathrm{K}_{\text {hat }}$ - Coefficient of agreement [25]was calculated using the following formula;

$$
\hat{K}=\frac{N \sum_{i=1}^{k} x_{i i}-\sum_{i=1}^{k}\left(x_{i+} \times x_{+i}\right)}{N^{2}-\sum_{i=1}^{k}\left(x_{i+} \times x_{+i}\right)}
$$

Where $k$ is the number of rows, $x_{i i}$ is the number of observations correctly classified for a particular category (summarized in the diagonal of the matrix), $x_{i+}$ and $x_{+i}$ are marginal totals for raw and column $i$ associated with the category, and $\mathrm{N}$ is the total number of observations in the entire error matrix. Kappa statistics is a measure of agreement or accuracy between remote sensing-derived classification map and the reference data. Looking at the 2013 users' accuracy on bare land and water, the scores highlight that having local knowledge of the study area has a bearing on the accuracy of the classification. Other studies have found the same pattern [26, 27].

\subsection{Land Use/Change Detection}

IDRISI Selva software[28] was used for land use/cover 
change detection. This was achieved through cross-tabulation of classified images using Change/Time series analysis tool (CROSS TAB). Classified images were cross-tabulated in pairs, that is 2000/2006 and 2006/2013 classified images. The results of cross-tabulation were summarized in a spreadsheet whereby the quantity and percentage of change of each land cover/use class were calculated.

\subsection{Land Use/Cover Change and Distribution Influencing Factors}

Multinomial logistic regression analysis was carried out using SPSS Version 17 to determine how the identified land use/cover drivers influence the existence of the observed land use/cover class in a specific location (spatial distribution) and observed LULC change. Classified images contained multiple categories of LULC classes, hence necessitated the choice of this analysis model [29]. Classified Land use/cover of 2000, 2006 and 2013 together with the eight LULC drivers were converted into polygons, overlaid and their database file was exported into SPSS as Y and $\mathrm{X}$ variables for statistical analysis. The LULC driving factors considered were graded maps of slope, elevation, distance from roads, distance from rivers, population density, annual rainfall, Normalized Difference Vegetation Index (NDVI) and soil types. The analysis outputs were individual logistic regression equations for each land use/cover category except for bare land class which was a reference category. The individual regression coefficients exponents $\left(\mathrm{e}^{\beta}\right)$ of the independent variables (odds ratio) were translated as the magnitude of the probable change in LULC due to change in one unit in independent variable in the logit model.The resulting logistic regression odds ratio values are presented in Table 7, 8 and 9.

The analysis of the influence of factors related to distribution of LULC on the landscape was performed using graphical analysis and interpretation of odds values. The classified images were cross-tabulated with the driving factors maps, and then the graphs of the cross-tabulated results were generated.

\section{Results and Discussions}

\subsection{LandUse/Cover Classification Accuracy}

The overall classification accuracy of the classification for 2000, 2006 and 2013 were 87.3, 85.4 and $85.7 \%$, respectively. The overall Kappa Statistics for the 2000 imagery was 0.86 while for 2006 and 2013 was 0.84 . The USGS satellite imagery classification scheme has set the minimum standard for accuracy assessment to be $85 \%[16,22]$. Generally, the results of classification accuracy assessment in this study are acceptable. Kappa values greater than 0.80 (i.e. $>80 \%$ ) represent strong agreement or accuracy between the classification made and the ground reference information [25]. Land use/cover type classes in Usangu catchment from the year 2000 to 2013 are shown in Fig.s 1 a-c. These figures clearly show that land use/cover types are not static over time. They change either naturally or under the influence of human activities.
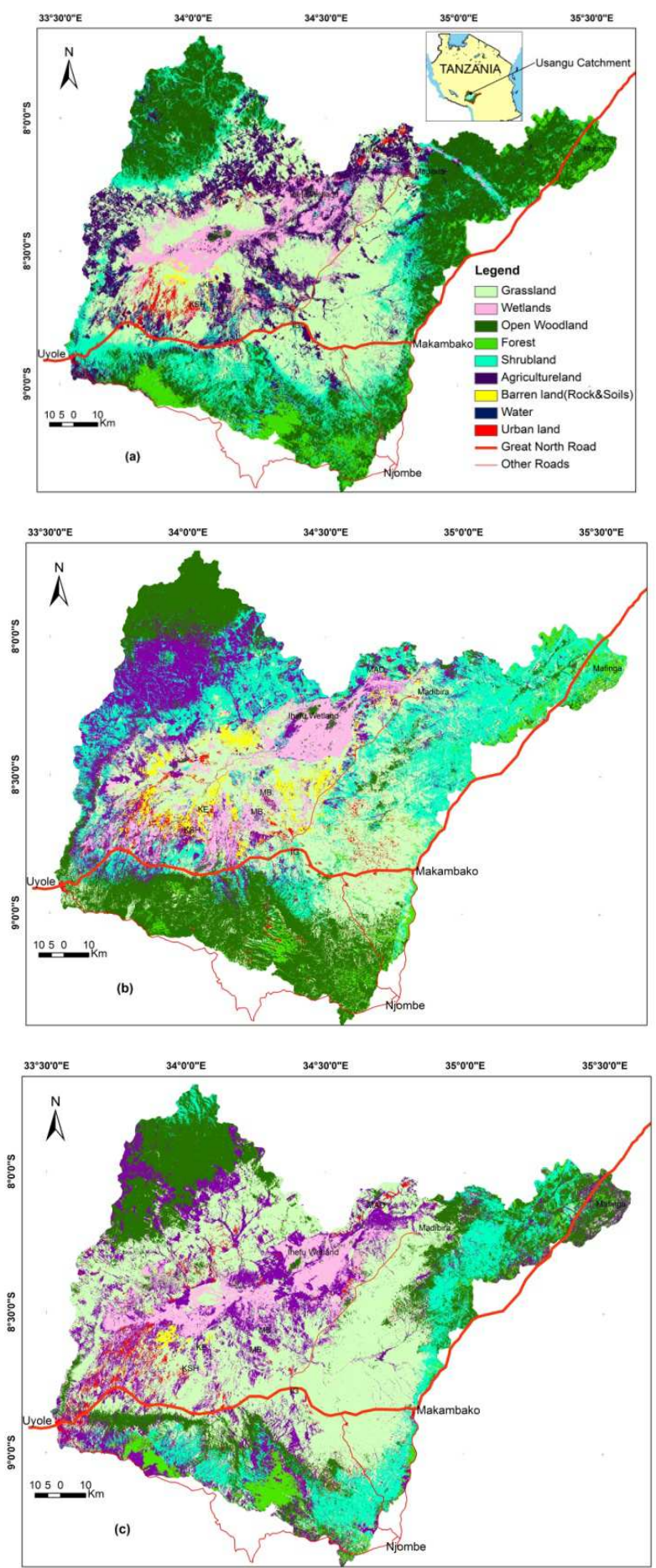

Fig. 1. LULC maps for Usangu Catchment for years (a) 2000 (b) 2006 (c) 2013.

Transition matrices in Tables 5 and 6 illustrate the changes of land uses in Usangu sub-catchment for the period between 2000 and 2013. Each row indicates the proportion (\%) of the original land use that changed into other land uses by the end of the period. Diagonal elements are the retention frequencies, that is, the lands of a given class that maintains its identity with no change to another LULC class. Last but one row in Tables 5 and 6 show the amount of gain or loss of each land 
class (in $\mathrm{km}^{2}$ ) between 2000/2006 and 2006/2013. The percentages of the change are shown in the last row of each table. Since the main economic activity in the study area is agriculture, discussion on changes on agricultural land is given due emphasis.

Table 5. Land use/cover change matrix $\left(\mathrm{km}^{2}\right)$ from 2000-2006.

\begin{tabular}{|c|c|c|c|c|c|c|c|c|c|c|c|}
\hline & & & & & 2000 & & & & & & \\
\hline & & GRA & WET & WOD & FOR & SHR & AGR & BAR & WAT & URB & 2006 Total \\
\hline \multirow{12}{*}{2006} & GRA & 2407.0 & 488.0 & 436.7 & 118.7 & 774.7 & 918.4 & 39.4 & 2.4 & 155.3 & 5340.6 \\
\hline & WET & 288.2 & 367.2 & 22.7 & 0.1 & 90.1 & 507.5 & 8.7 & 4.1 & 35.0 & 1323.5 \\
\hline & WOD & 449.7 & 58.3 & 1912.3 & 426.2 & 1209.1 & 378.8 & 0.7 & 3.5 & 28.7 & 4467.5 \\
\hline & FOR & 109.3 & 5.5 & 229.2 & 340.4 & 165.8 & 51.5 & 0.3 & 0.0 & 5.4 & 907.5 \\
\hline & SHR & 1196.9 & 113.6 & 1351.2 & 97.2 & 640.9 & 683.5 & 4.5 & 0.2 & 45.8 & 4133.6 \\
\hline & AGR & 902.4 & 274.1 & 862.0 & 13.4 & 646.6 & 632.7 & 13.3 & 1.2 & 81.7 & 3427.4 \\
\hline & BAR & 415.8 & 48.8 & 0.2 & 0.1 & 16.9 & 44.5 & 14.6 & 0.2 & 44.1 & 585.1 \\
\hline & WAT & 1.3 & 4.0 & 0.1 & 0.0 & 0.3 & 3.5 & 0.1 & 0.6 & 0.3 & 10.3 \\
\hline & URB & 242.5 & 52.4 & 18.1 & 12.6 & 105.3 & 2.6 & 3.7 & 0.9 & 76.4 & 514.5 \\
\hline & 2000 Total & 6013.0 & 1411.8 & 4832.6 & 1008.5 & 3649.6 & 3223.1 & 85.4 & 13.2 & 472.7 & 20709.9 \\
\hline & Change $\left(\mathrm{km}^{2}\right)$ & -672.4 & -88.4 & -365.1 & -101.0 & 484.0 & 204.2 & 499.8 & -2.8 & 41.8 & \\
\hline & Change (\%) & -11.2 & -6.3 & -7.6 & -10.0 & 13.3 & 6.3 & 585.5 & -21.6 & 8.8 & \\
\hline
\end{tabular}

Note: GRA: Grass land, WET: Wetland, WOD: Woodland, FOR: Forest, SHR: Shrubs, AGR: Agric, BAR: Bare land, WAT: Water, URB: Urban

Table 6. Land use/cover change matrix $\left(\mathrm{km}^{2}\right)$ from 2006-2013

\begin{tabular}{|c|c|c|c|c|c|c|c|c|c|c|c|}
\hline & & & & & 2006 & & & & & & \\
\hline & & GRA & WET & WOD & FOR & SHR & AGR & BAR & WAT & URB & 2013 Total \\
\hline \multirow{12}{*}{2013} & GRA & 3081.4 & 328.9 & 744.8 & 200.1 & 1691.9 & 1184.9 & 347.6 & 1.5 & 351.7 & 7932.9 \\
\hline & WET & 476.9 & 451.3 & 75.6 & 3.7 & 104.8 & 254.9 & 53.4 & 4.8 & 42.9 & 1468.5 \\
\hline & WOD & 210.1 & 40.1 & 1586.3 & 119.9 & 910.3 & 981.4 & 1.8 & 0.4 & 7.0 & 3857.4 \\
\hline & FOR & 87.4 & 0.1 & 299.6 & 216.5 & 70.8 & 9.1 & 0.0 & 0.0 & 7.9 & 691.5 \\
\hline & SHR & 306.4 & 1.1 & 759.8 & 190.4 & 647.4 & 88.4 & 0.1 & 0.0 & 17.2 & 2010.8 \\
\hline & AGR & 934.1 & 470.8 & 927.2 & 151.8 & 602.1 & 792.3 & 130.0 & 3.2 & 89.1 & 4100.6 \\
\hline & BAR & 45.0 & 4.2 & 0.3 & 0.3 & 4.8 & 15.4 & 19.8 & 0.0 & 3.6 & 93.3 \\
\hline & WAT & 1.4 & 1.6 & 7.1 & 0.9 & 0.8 & 1.0 & 0.1 & 0.3 & 0.5 & 13.6 \\
\hline & URB & 197.9 & 25.4 & 66.6 & 23.8 & 100.6 & 99.9 & 32.5 & 0.1 & 84.6 & 631.4 \\
\hline & 2006 Total & 5340.6 & 1323.5 & 4467.5 & 907.5 & 4133.6 & 3427.4 & 585.1 & 10.3 & 604.5 & 20799.9 \\
\hline & Change $\left(\mathrm{km}^{2}\right)$ & 2592.3 & 145.0 & -610.1 & -216.0 & -2122.8 & 673.2 & -491.8 & 3.2 & 26.9 & \\
\hline & Change (\%) & 48.5 & 11.0 & -13.7 & -23.8 & -51.4 & 19.6 & -84.0 & 31.4 & 4.4 & \\
\hline
\end{tabular}

The total area under agriculture in 2000 was $3223.1 \mathrm{~km}^{2}$ and $3427.4 \mathrm{~km}^{2}$ in 2006 . Between 2000 and 2006 , agricultural land expanded by $204.2 \mathrm{~km}^{2}(6.3 \%)$. This expansion of agricultural land resulted from converting other landuse/cover classes into agriculture as follows; Grassland $\left(902.4 \mathrm{~km}^{2}\right)$, Woodland $\left(862 \mathrm{~km}^{2}\right)$, Shrubs $\left(646.6 \mathrm{~km}^{2}\right)$ and Wetlands $\left(274.1 \mathrm{~km}^{2}\right)$. Similarly, between 2006 and 2013 agriculture land expanded by 19.6\%). Major land classes of 2006 which were converted to agriculture in 2013 are Grasslands (934.1 $\left.\mathrm{km}^{2}\right)$, Woodlands $\left(927.2 \mathrm{~km}^{2}\right)$, Shrubs $\left(602 \mathrm{~km}^{2}\right)$ and Wetlands $\left(470.8 \mathrm{~km}^{2}\right)$. Here, major agricultural expansion has taken place in the grassland areas, although woodland, shrubs and wetlands conversions are also significant.

Results in Tables 5 and 6 show that forests are being converted mainly into woodlands, shrubs and agriculture. On the other hand, wetlands are converted mainly to grasslands and agriculture both in 2000-2006 and 2006-2013. Looking into land uses/covers which have been converted into agriculture in 2006 and 2013; it implies that agriculture extends to areas with favourable features for crops that are cultivated in the study area. Major lands which are being converted to urban class are grasslands and shrubs.

\subsection{Determinants of Landuse/Cover Change and Distribution}

The multinomial logit regression used in this study involved eight LULC change and distribution factors as earlier mentioned in Introduction section. The individual regression odds ratio values results from analysis are shown in Tables 7, 8 and 9.

The magnitude of probability (Odds) of a change of a particular LULC to another is indicated by the magnitude of the Odds ratio values. The odds ratio represents the change in odds of being in one of the categories of outcome when the value of a predictor increases by one unit, controlling for other factors in the model [30]. The Odds ratio value less than 1 in this table shows how less likely the change in LULC occurs as a result in the additional 1 unit of the independent variable. Odds ratio value greater than 1 indicates the number of times the change is more likely to occur compared to the reference dependent category. The amount of change can be significant or non-significant. The non-significant cases $(p>0.05)$ in Tables 7, 8 and 9 are denoted by an asterisk “*”. The changes in LULC due to effects of increasing the driving factor by one unit are significant if $p<0.05$. In this research, LULC classes and soil types were categorical data while other factors were 
continuous data. During the multinomial logistic regression analysis, bare land was purposively considered as the reference category while Nitisols (Soils8) was taken as a reference category for soil type classes.

Table 7. Results of Logistic Regression (Odds ratios) for LULC in 2000.

\begin{tabular}{|c|c|c|c|c|c|c|c|c|c|}
\hline & & \multicolumn{8}{|l|}{ LULC } \\
\hline & & GRA & WET & WOD & FOR & SHR & AGR & WAT & URB \\
\hline \multirow{15}{*}{ Factors } & Slope & 1.890 & 1.236 & 1.768 & 1.549 & 1.742 & 1.767 & 1.595 & 1.438 \\
\hline & Elevation & 3.488 & $1.020 *$ & 7.631 & 14.372 & 4.716 & 3.150 & 3.124 & 2.076 \\
\hline & D-Roads & 1.432 & 1.603 & 2.135 & 1.850 & 2.033 & 1.507 & 1.620 & 1.133 \\
\hline & D-Rivers & 1.371 & 1.257 & 1.165 & 1.179 & 1.169 & 1.584 & 1.217 & 1.320 \\
\hline & P-Density & 2.008 & 1.819 & 1.950 & 2.044 & 2.105 & 1.883 & 2.825 & 2.209 \\
\hline & Annual Rain & 1.388 & 0.428 & 2.671 & 6.302 & 2.398 & 1.581 & 3.734 & 2.238 \\
\hline & NDVI & 2.507 & 2.738 & 4.290 & 1.802 & 3.084 & 2.817 & 6.953 & 1.857 \\
\hline & [Soils1] & $0.557^{*}$ & 0.016 & 0.078 & 0.057 & $0.301 *$ & $2.375^{*}$ & 979.863 & $6.534 *$ \\
\hline & [Soils2] & $0.496^{*}$ & 0.023 & 0.038 & 0.001 & $0.258 *$ & $3.605 *$ & 5620.257 & $4.853 *$ \\
\hline & [Soils3] & $1.249 *$ & 0.010 & 0.255 & 0.002 & $0.877^{*}$ & $3.677^{*}$ & 6.011 & $7.077^{*}$ \\
\hline & [Soils4] & $0.547 *$ & 0.019 & 0.107 & 0.077 & $0.459 *$ & $3.129 *$ & 1112.108 & 10.415 \\
\hline & [Soils5] & $5.880 *$ & 0.022 & $0.383 *$ & 0.004 & $3.067 *$ & 10.758 & 1333.821 & 29.857 \\
\hline & [Soils6] & $1.347 *$ & 0.026 & 0.059 & 0.004 & $0.311 *$ & $5.528 *$ & 102.077 & 27.312 \\
\hline & [Soils7] & $2.853 *$ & $0.151 *$ & $2.069^{*}$ & $1.907 *$ & $3.349 *$ & 8.622 & 3785.201 & 35.868 \\
\hline & [Soils8](Ref) & - & - & - & - & - & - & - & - \\
\hline
\end{tabular}

${ }^{*} p<0.05$, LULC reference category is Bare land, Soil types reference category is Soils8 (Nitisols)

Note: D-Roads $=$ Distance from Roads-Rivers=Distance from Rivers-Density=Population Density, Soils1=Leptosols, Soil2=Fluvisols, Soil3=Cambisols,

Soil4=Andosols, Soil5=Lixisols, Soil6=Solonetz, Soil7=Acrisols, Soil8=Nitisols

Table 8. Results of Logistic Regression (Odds ratios) for LULC in 2006

\begin{tabular}{|c|c|c|c|c|c|c|c|c|c|}
\hline & & \multicolumn{8}{|l|}{ LULC } \\
\hline & & GRA & WET & WOD & FOR & SHR & AGR & WAT & URB \\
\hline \multirow{15}{*}{ Factors } & Slope & 1.064 & 1.217 & 1.069 & $1.002 *$ & 1.086 & 1.160 & .467 & .930 \\
\hline & Elevation & 4.352 & 1.873 & 7.062 & 10.247 & 5.231 & 3.932 & .485 & 3.926 \\
\hline & D-Roads & 1.115 & 1.038 & 1.549 & 1.554 & 1.270 & 1.421 & 3.494 & .883 \\
\hline & D-Rivers & 1.079 & 0.717 & 0.983 & 0.970 & 1.107 & $0.998 *$ & .717 & .958 \\
\hline & P-Density & 0.905 & 0.779 & 0.745 & 0.959 & 0.722 & 0.741 & 1.670 & 1.241 \\
\hline & Annual Rain & 0.846 & 0.292 & 1.087 & 1.162 & 0.559 & 0.640 & $1.020 *$ & 1.189 \\
\hline & NDVI & 24.454 & 130.326 & 188.067 & 12.899 & 49.692 & 73.622 & 147.695 & 4.777 \\
\hline & [Soils1] & 0.015 & $0.405^{*}$ & 0.007 & 0.002 & 0.004 & 0.019 & $.109 *$ & .051 \\
\hline & [Soils2] & 0.016 & $0.590 *$ & 0.007 & 0.002 & 0.003 & 0.016 & $.147 *$ & .039 \\
\hline & [Soils3] & 0.024 & 0.159 & 0.008 & 0.003 & 0.013 & 0.044 & $.007 *$ & .038 \\
\hline & [Soils4] & 0.018 & $0.283^{*}$ & 0.010 & 0.003 & 0.003 & 0.013 & $.044 *$ & .067 \\
\hline & [Soils5] & 0.053 & 0.144 & 0.027 & 0.014 & 0.012 & 0.029 & $.070 *$ & .256 \\
\hline & [Soils6] & 0.055 & $0.263^{*}$ & 0.014 & 0.017 & 0.014 & 0.043 & $.009 *$ & .059 \\
\hline & [Soils7] & 0.074 & $0.973 *$ & 0.046 & 0.025 & 0.031 & 0.058 & $.176^{*}$ & .176 \\
\hline & [Soils8](Ref) & - & - & - & - & - & - & - & - \\
\hline
\end{tabular}

$*_{p}<0.05$, LULC reference category is Bare land, Soil types reference category is Soils8 (Nitisols)

Table 9. Results of Logistic Regression (Odds ratios) for LULC in 2013.

\begin{tabular}{|c|c|c|c|c|c|c|c|c|c|}
\hline & & \multicolumn{8}{|l|}{ LULC } \\
\hline & & GRA & WET & WOD & FOR & SHR & AGR & WAT & URB \\
\hline \multirow{15}{*}{ Factors } & Slope & 1.740 & 1.323 & 1.753 & 1.344 & 1.587 & 1.515 & 2.003 & 1.414 \\
\hline & Elevation & 2.720 & 1.344 & 2.540 & 8.310 & 5.020 & 2.204 & 2.326 & 2.265 \\
\hline & D-Roads & 1.853 & 1.717 & 2.568 & 4.244 & 4.537 & 1.914 & 3.400 & $1.028^{*}$ \\
\hline & D-Rivers & 1.498 & 1.532 & 1.162 & 1.425 & 1.197 & 1.418 & 1.116 & 1.308 \\
\hline & P-Density & 1.427 & 1.417 & 1.291 & 1.296 & 2.032 & 1.381 & 2.031 & 1.736 \\
\hline & Annual Rain & 2.646 & 1.639 & 4.114 & 11.438 & 4.815 & 4.857 & 8.746 & 3.419 \\
\hline & NDVI & 1.256 & 0.551 & 0.394 & 0.625 & 0.486 & 0.525 & 0.416 & 1.085 \\
\hline & [Soils1] & 1.444 & 16.007 & 0.085 & 0.027 & 0.149 & 0.273 & 0.109 & 0.368 \\
\hline & [Soils2] & $1.171 *$ & 33.526 & 0.055 & 0.001 & 0.000 & 0.481 & $1.203 *$ & 0.218 \\
\hline & [Soils3] & 6.907 & 57.276 & 0.288 & 0.000 & 0.057 & 0.622 & 0.007 & 2.204 \\
\hline & [Soils4] & 4.893 & 35.945 & 0.427 & 0.099 & $0.766^{*}$ & $0.931 *$ & 0.601 & 1.396 \\
\hline & [Soils5] & 90.169 & 238.227 & 7.007 & 0.090 & 4.736 & 8.116 & 2.363 & 9.137 \\
\hline & [Soils6] & 5.440 & 22.756 & 0.244 & 0.010 & 0.012 & 0.605 & 0.008 & 5.163 \\
\hline & [Soils7] & 14.156 & 16.364 & 2.338 & 1.206 & 9.620 & 2.224 & 1.675 & 4.875 \\
\hline & [Soils8](Ref) & - & - & - & - & - & - & - & - \\
\hline
\end{tabular}

$*_{p}<0.05$, LULC reference category is Bare land, Soil types reference category is Soils8 (Nitisols) 
The results in Tables 7, 8 and 9 present three types of information. First, Odds (probability) of dependent variable (LULC classes) to change as a result of change in one unit of an independent variable. Second, possibility of change in space of one LULC class to another as one move spatially from one category to another of the same influencing factor, example from low elevation to high elevation, or from one soil type to another.

Although the logistic regression model was set in such a way that LULC (dependent variable) was influenced by several factors, some of the factors change with time while others do not. For example elevation and slope do not change with time but do so across the landscape. Annual rainfall, population density and NDVI change with time; and this change determines LULC. The nature of land geomorphology (slope and elevation) acts as natural barriers to landscape ecosystem change by limiting at different degrees the movement of human activities. Steep slopes and high elevations, for example, favour forests, grasses but discourage agriculture. Hence, these two factors account for the existing distribution of LULC distributions on a given geographical location.

\subsubsection{LandUse/Land Covers Change}

General analysis of the odds ratio values shown in Tables 7 , 8 and 9 indicate that compared to other factors, elevation, annual rainfall, NDVI and soil types bear large values in almost all land use classes. The higher the odds ratio values, the higher the probability of that particular LULC class to change as a result of changing the magnitude of independent factor by one unit $[31,32]$. The odds ratio associated with soil types are all less than one $(\mathrm{OR}<1)$ almost in all LULC classes except grasslands (2000\&2013), wetlands (2013), water (2000\&2013) and urban (2000\&2013). This implies that the spatial change in soil typesalso leads to changes in spatial distribution of grassland, water, urban lands and wetlands.

It can also be noted that even in cases where odds ratio values associated with soil types are statistically significant, the effect of the change is small $(\mathrm{OR}<1)$. This implies that, compared to bare land, chances are low for LULC to change on different soil types across the landscape. Interesting results associated with soil types can be seen on soils 5 (Lixisols) and soil7 (Acrisols), respectively. The odds ratios for these soils are higher under wetlands, grasslands, agricultural lands, water and urban lands. These two soils are characterized with subsurface accumulation of low activity clays, whereby Lixisols have higher base saturation than Acrisols. They are older, well-formed and deep soils which favor agriculture. Conversion of grassland and wetlands to agriculture is a common feature in the study area (Table 5 and 6). Therefore, these soils determine spatial distribution of agriculture and wetlands in the study area. Spatial change to other soil types leads to great LULC changes associated with agriculture, wetlands and grass lands.

Odds ratio associated with slope and distance from water networks do not show great variations in Tables 7, 8 and 9. Almost all values for distance from rivers are less than 1 . So the influences of these two independent variables are less discussed in this paper. A study by Cihlar et al. (2001) found that slope class has a strong relation with land use class. Lands on the steep areas are always related to land uses like forestry and pastures and meadows.

The influence of each factor on LULC change and distribution as shown by odds ratio values in Tables 7,8 and 9 are further summarized in terms of the decreasing magnitude of odds ratio in Table 10. This summary shows the most affected LULC class when the selected factors magnitudes are changed by one unit in a particular year of observation.

Table 10. Odds ratio of change of selected LULC (Decreasing in magnitude) under different factors.

\begin{tabular}{llll}
\hline Factor & $\mathbf{2 0 0 0}$ & $\mathbf{2 0 0 6}$ & $\mathbf{2 0 1 3}$ \\
\hline Elevation & FOR $>$ WOD $>$ SHR $>$ GRA $>$ AGR & FOR $>$ WOD $>$ SHR $>$ GRA $>$ AGR & FOR $>$ SHR $>$ GRA $>$ WOD $>$ WAT \\
D-Roads & WOD $>$ SHR $>$ FOR $>$ WAT & WAT $>$ FOR $>$ WOD $>$ AGR & SHR $>$ FOR $>$ WAT $>$ WOD \\
P-Density & WAT $>$ URB $>$ FOR $>$ GRA & WAT $>$ URB $>$ FOR $>$ GRA & SHR $>$ WAT $>$ GRA $>$ WET $>$ AGR \\
Annual rain & FOR $>$ WAT $>$ WOD & URB $>$ FOR $>$ WOD & FOR $>$ WAT $>$ AGR \\
NDVI & WAT $>$ WOD $>$ SHR $>$ WET $>$ GRA & WOD $>$ WAT $>$ WET $>$ SHR $>$ GRA & GRA $>$ URB $>$ FOR $>$ WET $>$ AGR \\
Soil[5] & WAT $>$ URB $>$ AGR $>$ GRA $>$ SHR & URB $>$ WET $>$ WAT $>$ GRA & WET $>$ GRA $>$ URB $>$ AGR $>$ WOD \\
Soil[7] & WAT $>$ URB $>$ AGR $>$ SHR $>$ GRA & WET $>$ URB $>$ WAT $>$ GRA & WET $>$ GRA $>$ SHR $>$ URB $>$ WOD \\
\hline
\end{tabular}

Generally, Table 10 shows that elevation determines greatly the distribution of forestlands, woodlands and shrubs compared to the reference land category. Field observation shows that the higher the altitude, the more the forests and woodlands. It can also be note that increase of distances from roads also affects distribution of forests, woodlands and water bodies. Population density has great impacts on water bodies, urban lands, grasslands and wetlands. Changes in forest lands, woodlands and water resources are also controlled by the amount of annual precipitation. Changes in annual precipitation affect much these types of LULC classes.

\subsubsection{Land use/land Covers Distribution}

Landscapes in Usangu watershed are covered by wide variations of biological as well as physical features. There is a distinct change in vegetation from the highlands to the lowlands. The existence of such land use/cover types across the watershed landscape is a function of many factors ranging from demographic, climatic, edaphic and socialeconomic aspects. These factors also influence the changes in LULC which take place in a catchment $[15,29]$. This study has shown that there is close relationship between the 
distribution and existence of a given LULC with annual rainfall, elevation and soil types. However, the existence and distribution of LULC are mainly influenced by geomorphologic/relief, climatic or edaphic factors. The influence of elevation on LULC is demonstrated in Fig. 2.

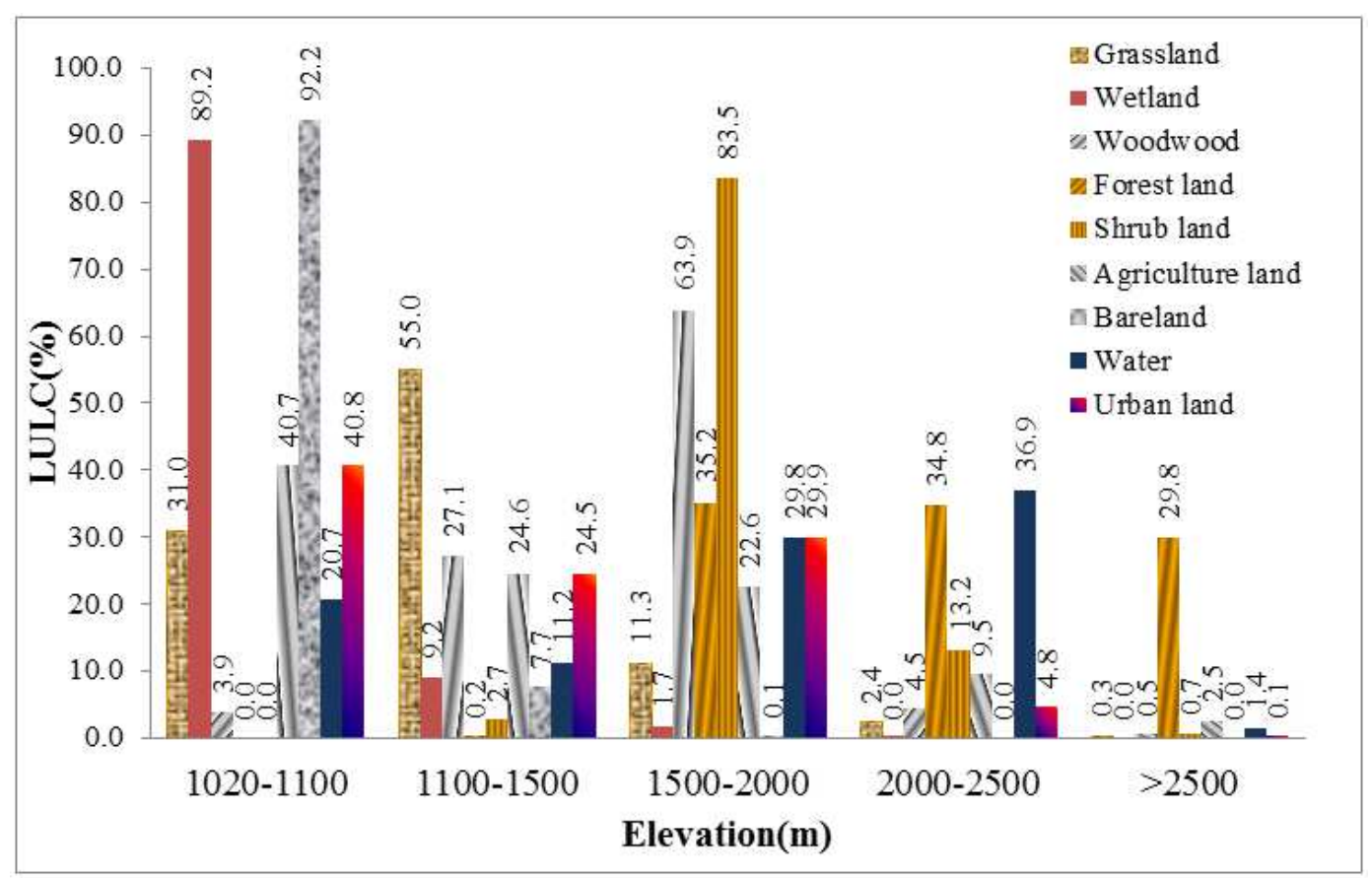

Fig. 2. LULC distribution along elevation grades.

Agriculture, which is the main economic activity in the Usangu plains, is dominant in low elevation areas (1020$1100 \mathrm{~m}$ amsl). By 2013 , itoccupied about $40.7 \%$ of all land area, and its size decreases as the elevation increases. At $2000-2500 \mathrm{~m}$ amsl, it occupies only $9.5 \%$ of all the land cover. This pattern of distribution can be attributed to elevation barrier. As elevation increases, accessibility to the area and agricultural activities become difficult. Similarly, Fig.3depicts reduced human settlementswith increase in altitude. Large population is found in elevations from 1100$2000 \mathrm{~m}$ amsl, then decreases drastically to areas located at 2000-2500m amsl. Low population in high altitude areas gives a room for existance of forests and woolands. Agricultural land and urban areas are also distributed mainly in these areas. Agricultural activities are dominant in wetlands which are located in low altitudes (less than $1100 \mathrm{~m}$ amsl).

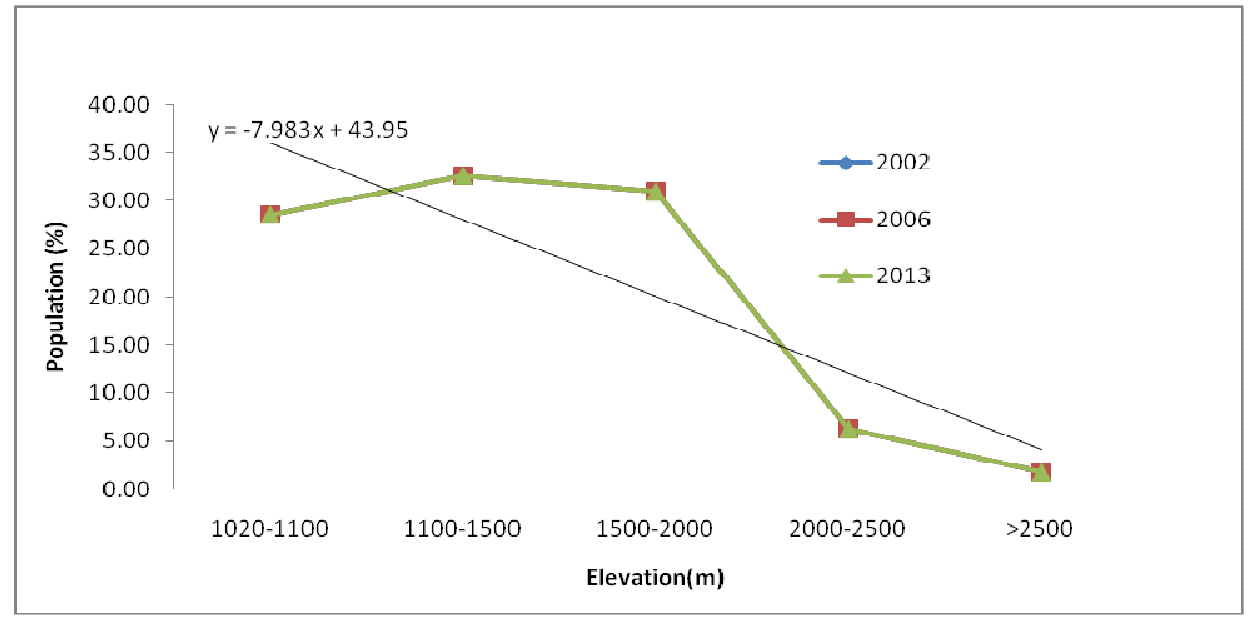

Fig. 3. Changes in population densitywith altitude in Usangu Catchment.

Distribution of LULC based on elevation trend has been reported in previous studies and resulted almost the same as the one reported in this study. Remnant montane humid forestare found above $2,000 \mathrm{~m}$ amsl while Miombo woodland dominates the elevations between $2,000 \mathrm{~m}$ and $1,100 \mathrm{~m}$ amsl [18]. Areas below $1,100 \mathrm{~m}$ amsl are dominated by the fans and Usangu wetlands. The fans are fertile and consequently many agricultural activities are concentrated here. 


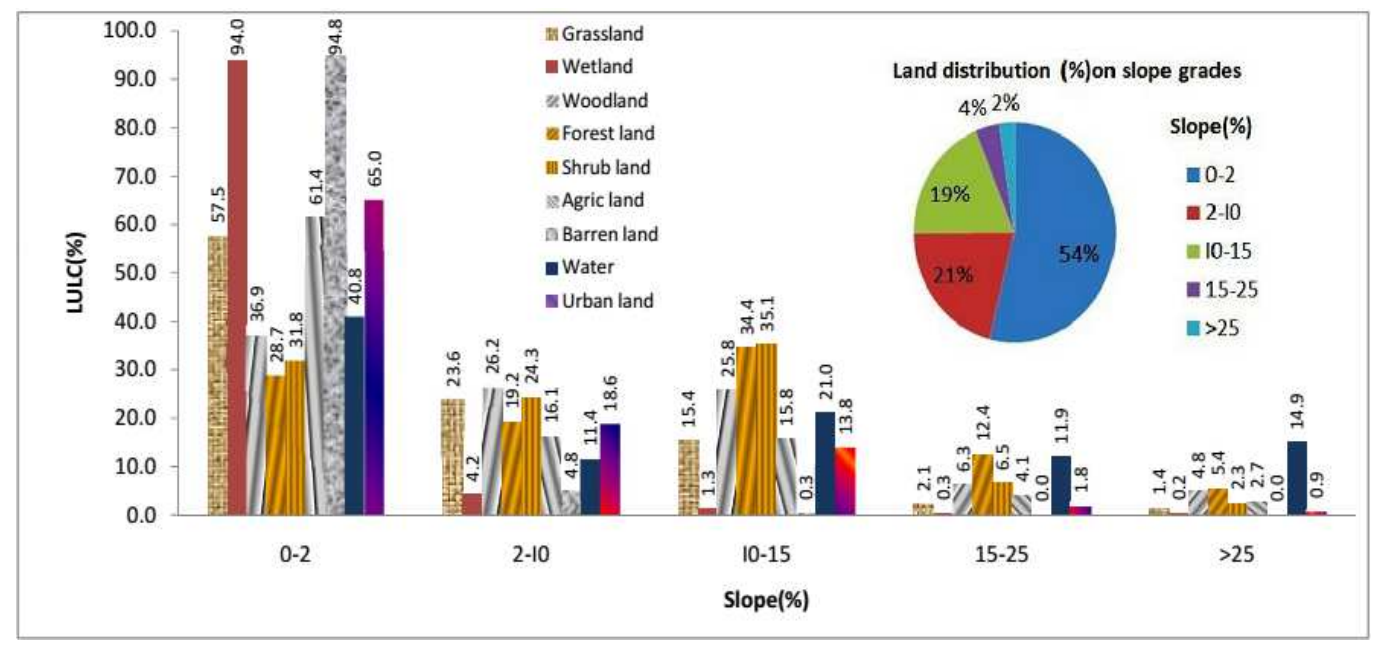

Fig. 4. LULC distribution on slope grades (bar chart) and total LULC in each slope grade (pie chart).

As discussed earlier, terrain in landscapes determines human activities. Evidence from field observation shows reduced human activities in terms of tree cutting and charcoal burning with increase in altitude. Conversely, flatness of the area encourages the type of economic activities that take place in Usangu catchment. For this reason, large part of the flat areas (0-2\% slope)is occupied by different LULC types as indicated in Fig 4. Similarly, a pie chart inserted in Fig.4 shows that about $54 \%$ ofthe area covered by Usangu catchment lies in the slope measuring $0-2 \%$. Steep slopes hinders infrustuctural development like roads, irrigation schemes and houses for settlements. This explains why urban areas $(65.0 \%)$ lie between $0-2 \%$ slope. Steep areas (slope of $10-15 \%, 15-25$ and $>25 \%$ ) are dominated by trees and shrubs, but in the decreasing magnitude. Moderate slope (10-15\%) to steep area (15-25\% slope) can be tolerated by big trees, but very steep slopes $(25 \%$ slope $)$ coupled with shallow soils discouaragesexistance of big trees as there may be frequent land slides and soil erosion [2].

Distance from roads is another important predictor of distribution of certain LULC types; of special interests in this study are urban and agricultural lands. Current lands occupied by these LULC classes are a result of converting other land covers like forests, shrubs or grass lands in support of economic activities such as transportation and irrigation. Major irrigation schemes in the study area (e.g. Kapunga, Igomelo, Mbarali Estates, Madibira and Ihahi) are close to road networks. In general, roads attract human settlements. Fig. 5 shows that about $95.3 \%$ of urban land (settlements) is found within 0-10 kilometers from road networks, while $2.3 \%$ and $0.9 \%$ of urban lands are found at $10-20 \mathrm{~km}$ and $30-$ $40 \mathrm{~km}$, respectively. On the other hand, agricultural lands $(48.6 \%)$ are distributed within $0-10 \mathrm{~km}$ from roads. This proportion decreases slowly as distance from roads reaches to as far as $40-50 \mathrm{kms}(6.3 \%)$.

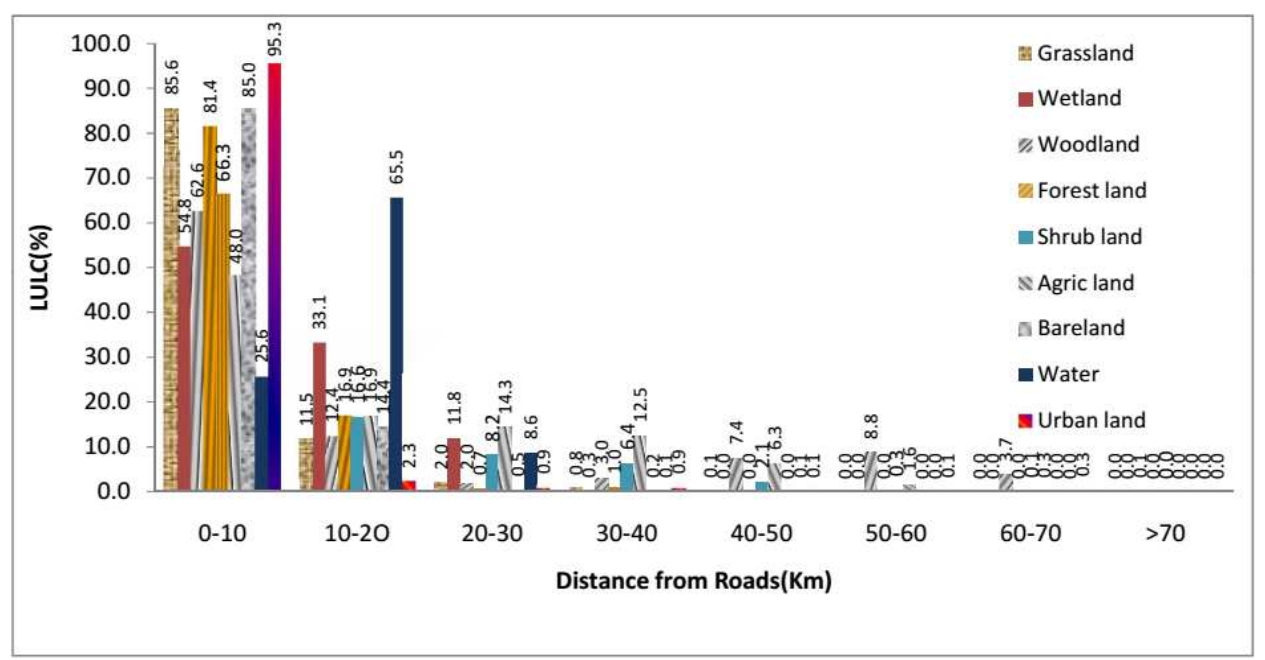

Fig. 5. LULC distribution with respect to distance from the roads network in Usangu catchment.

As shown earlier in Tables 7,8 and 9 and summary of results in Table 10, amount of annual rainfall distribution determines distribution of certain LULC classes. Information in Fig.6 gives further details of the influence of rainfall on 
LULC distribution. Here, forest land, woodlands, water bodies and for small extent agriculture, their distribution is clearly seen as a function of amount of annual rainfall.Mountain areas in Usangu catchment (Kipendege and Poroto Mountains) receive higher annual rainfall compared with the low lands. Previous study [33] in Usangu watershed found out that land use/cover change has relationship with rainfall amounts, whereby land covers do fluctuate from year to year depending on the differences in rainfall between years. Inverse relationship is seen on agricultural lands and annual rainfall.

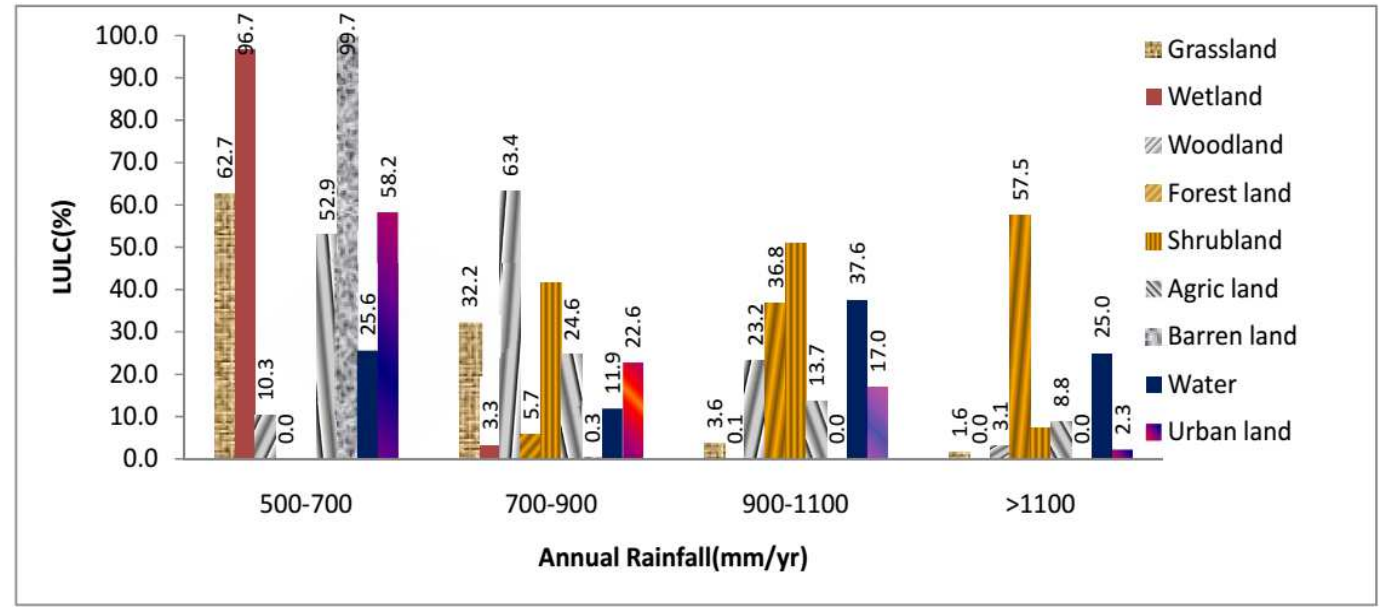

Fig. 6. LULC percentages as distributed in different annual rainfall amounts.

The distribution of agricultural lands is higher in low annual rainfall areas and low in higher annual rainfall areas. This is due to the fact that excessive rains fall on the mountain where it is unsuitable for agriculture. On the contrary, the rain water recharges groundwater and some flows as rivers to low elevation areas where soils are suitable for farming.

\section{Conclusion}

This study has identified LULC changes which have taken place in Usangu catchment from 2000 to 2013 and theirrelated factors that have contributed to these changes. Although LULC changes can be attributed to natural factors, findings of this study suggest that anthropogenic changes had strong influence on LULC changes and distribution. We note that grasslands, shrubs and wetlands are being converted into agricultural lands and settlements/urban lands. The degree of influence on LULC changes and LULC distribution varies with specific factors. While some factors have more influence on land use change (annual rainfall, population density and distance from road networks), others (terrain and edaphic factors) are important determinants of LULC distribution. This study also shows that ingeniously integration of remote sensing, GIS application combined with multisource spatial data and analysis give great possibility of quantifying and explaining the LULC changes and LULC distribution in terms of time and space. The approach of identification, testing and analysis of influence of each factor that determine the existence of a certain LULC at a certain location and at a given time provides foundation for advanced analysis like Markov chain and water balance studies of the catchment.

\section{References}

[1] Koomen, E. and J. Stillwell, Modelling land-use change. 2007: Springer.

[2] Hyandye, C. and I. Katega, Natural Barriers to Ecoenvironmental Vulnerability in a Complex Ecosystem. Journal of Environmental Science and Engineering, 2010. 4(9): p. 32-39.

[3] Antrop, M., Landscape change and the urbanization process in Europe. Landscape and urban planning, 2004. 67(1): p. 9-26.

[4] Cihlar, J. and L.J. Jansen, From land cover to land use: a methodology for efficient land use mapping over large areas. The Professional Geographer, 2001. 53(2): p. 275-289.

[5] Peña, J., et al., Driving forces of land-use change in a cultural landscape of Spain, in Modelling land-use change. 2007, Springer. p. 97-116.

[6] Bürgi, M., A.M. Hersperger, and N. Schneeberger, Driving forces of landscape change-current and new directions. Landscape Ecology, 2004. 19(8): p. 857-868.

[7] Wood, R. and J. Handley, Landscape dynamics and the management of change. Landscape Research, 2001. 26(1): p. $45-54$

[8] Verburg, P.H., et al., Determinants of land-use change patterns in the Netherlands. Environment and Planning B, 2004. 31(1): p. $125-150$.

[9] Giri, C., P. Defourny, and S. Shrestha, Land cover characterization and mapping of continental Southeast Asia using multi-resolution satellite sensor data. International Journal of Remote Sensing, 2003. 24(21): p. 4181-4196.

[10] Lambin, E.F., H.J. Geist, and E. Lepers, Dynamics of land-use and land-cover change in tropical regions. Annual review of environment and resources, 2003. 28(1): p. 205-241. 
[11] Jansen, L., G. Carrai, and M. Petri, Land-use change at cadastral parcel level in Albania, in Modelling Land-Use Change. 2007, Springer. p. 25-44.

[12] Kikula, I., Charnley, S., Yanda, P., Ecological changes in the Usangu Plains and their implications on the downstream flow of the Great Ruaha river in Tanzania. Research Report No.99. 1996, Institute of Resource Assessment: Dar es Salaam.

[13] Kashaigili, J.J., et al., Dynamics of Usangu plains wetlands: Use of remote sensing and GIS as management decision tools. Physics and Chemistry of the Earth, Parts A/B/C, 2006. 31(15): p. 967-975.

[14] Kashaigili, J.J., Impacts of land-use and land-cover changes on flow regimes of the Usangu wetland and the Great Ruaha River, Tanzania. Physics and Chemistry of the Earth, Parts A/B/C, 2008. 33(8-13): p. 640-647.

[15] Behera, D., et al., Modelling and analyzing the watershed dynamics using Cellular Automata (CA)-Markov model-A geo-information based approach. Journal of earth system science, 2012. 121(4): p. 1011-1024.

[16] Weng, Q., Land use change analysis in the Zhujiang Delta of China using satellite remote sensing, GIS and stochastic modelling. Journal of environmental management, 2002. 64(3): p. $273-284$.

[17] Shu, Y. and K.G. Villholth, Analysis of Flow and Baseflow Trends in the Usangu Catchment, Tanzania. IWMI, International Water Management Institute, Pretoria, South Africa.

http://www.ru.ac.za/static/institutes/iwr/SANCIAHS/2012/doc uments/047_Shu.pdf 2012.

[18] SMUWC, Final Report, Water Resources. Supporting report 7 , Directorate of Water Resources, Dar es salaam, Tanzania. 2001a. p. 81.

[19] Kadigi, R.M., et al., Water for irrigation or hydropower generation?-Complex questions regarding water allocation in Tanzania. Agricultural water management, 2008. 95(8): p. 984-992.

[20] Geosystems, L., ERDAS imagine. 2011: Atlanta,Georgia.

[21] ESRI, ArcGIS Desktop 10.1. 2011, Environmental Systems Research Institute: Redlands, CA.
[22] Anderson, J.R., et al., A land use and land cover classification system for use with remote sensor data: US Geological Survey Professional Paper 964,28. Washington,1976.

[23] Kiptala, J., et al., Land use and land cover classification using phenological variability from MODIS vegetation in the Upper Pangani River Basin, Eastern Africa. Physics and Chemistry of the Earth, Parts A/B/C, 2013. 66: p. 112-122.

[24] Lillesand, T.M. and R.W. Kiefer, Remote sensing and image interpretation. 1994, Wiley, New York.

[25] Jensen, J.R., Introductory Digital Image Processing: A Remote Sensing Perspective. 2007: Prentice Hall.

[26] Naidoo, R. and K. Hill, Emergence of indigenous vegetation classifications through integration of traditional ecological knowledge and remote sensing analyses. Environmental Management, 2006. 38(3): p. 377-387.

[27] Molnár, Z., et al., Distribution of the (semi-) natural habitats in Hungary I. Marshes and grasslands. Acta Botanica Hungarica, 2008. 50: p. 59-105.

[28] Labs, C., IDRISI Selva v17. GIS and Image Processing Software 2012 .

[29] Abdel-Kader, F.H., Digital soil mapping at pilot sites in the northwest coast of Egypt: A multinomial logistic regression approach. The Egyptian Journal of Remote Sensing and Space Science, 2011. 14(1): p. 29-40.

[30] Tabachnick, B. and L. Fidell, Multivariate analysis of variance and covariance. Using multivariate statistics, 2007. 3: p. 402407.

[31] Westergren, A., et al., Eating difficulties, need for assisted eating, nutritional status and pressure ulcers in patients admitted for stroke rehabilitation. Journal of clinical nursing, 2001. 10(2): p. 257-269.

[32] $\mathrm{Hu}, \mathrm{Z}$. and C. Lo, Modeling urban growth in Atlanta using logistic regression. Computers, Environment and Urban Systems, 2007. 31(6): p. 667-688.

[33] Kashaigili, J.J., et al. Integrated hydrological modelling of wetlands for environmental management: the case of the Usangu wetlands in the Great Ruaha catchment. in RIPARWIN Seminar Presentation, Sokoine Univ. of Agric. Morogoro, Tanzania. 2005. 